How to cite: Amihaesei, V.-A., Apostol, L., Dumitrescu, A. (2020) An Approaching on Estimating of Snow Depth and Snow Water Equivalent. 2020 "Air and Water - Components of the Environment" Conference Proceedings, Cluj-Napoca, Romania, p. 201-212, DOI: 10.24193/AWC2020_19.

\title{
AN APPROACHING ON ESTIMATING OF SNOW DEPTH AND SNOW WATER EQUIVALENT
}

\author{
Vlad-Alexandru AMIHAESEI ${ }^{1}$, Liviu APOSTOL ${ }^{1}$, \\ Alexandru DUMITRESCU ${ }^{1}$
}

DOI: 10.24193/AWC2020_19

\begin{abstract}
Snow water equivalent (SWE) and snow depth (SD) is estimating using Snow 17 model for several meteorological mountain stations from Romania. The model uses air temperature as the sole index to determine the energy exchange across the snow-air interface. In addition to temperature, the only other input variable needed to run the model is precipitation. The estimating values was validated with measurements values from respective point stations. It was observed that depending on the elevation station the values estimated have different errors. It is a strong correlation between estimating and observed values of SWE for Sinaia station $(r=0.96)$, Balea Station $(r=0.92)$, whereas for Vf. Omu station the correlation is weaker $(r=0.82)$. Regarding the SD values, the negligible difference can be found between modelled and observed data. Importantly, this study validates a model applied to the several meteorological stations from Romania.
\end{abstract}

Keywords (4-6): climate change, modelling, estimated, snow water equivalent, melt process, precipitation, temperature

\section{INTRODUCTION}

The proprieties of the snow are considered to be an indicator of climate change because of its sensitivity to temperature (Mankin et al., 2015; Bojariu, 2007). The snow pack strongly influences the overlying air, the underlying ground and the atmosphere downstream (Brown, 2000). Climate warming has decreased the proportional amount of snowfall versus rainfall (Trenberth, 2011), reduced snow water equivalent (SWE) accumulation (Caian, 2001), shifted snowmelt earlier in spring (Steward, 2009). Changes in snow cover (SC), snow depth (SD) and snow water equivalent (SWE) affect the climate system through ice-albedo feedback which is a strong positive feedback (Bojariu, 2015; Micu, 2015; Dumitrescu, 2015).

According to Intergovernmental Panel on Climate Change the increase of the surface temperature in high latitudes will delay the beginning of the snow accumulation period. Moreover, modelling the snow-albedo feedback represent large source of uncertainty in LSM simulations of future hydroclimatic conditions.

\footnotetext{
1 "Alexandru Ioan Cuza" University of Iași, Romania, Faculty of Geography and Geology, e-mail: boicu.d.daniel@gmail.com apostolliv@yahoo.com
} 
On the other hand, the increase of atmospheric moisture content may cause an increase in snowfall. These two opposite reasons make it difficult to determine whether the SWE will increase or decrease. Changes in snow and its seasonal march will affect climate, water resources such as river discharge, and human living conditions.

Observations of SWE or snow depth have also been provided by remote sensing, such as laser scanning technology (Prokop et al., 2008; Grünewald et al., 2010), scanning microwave radiometers (Dahe et al., 2006) or from Sentinel SAR (Lievens, 2019).

In Romania, the decrease in snow depth affects a good part of the country, especially, in the intra-Carpathian region and Northeastern Romania. Bîrsan et.al, 2014 has showed the most dramatic change concerns the number of snowfall days, which is decreasing at $82 \%$ of the locations.

Snowfall dominates precipitation in the mountains and snow accumulation varies because of topography, vegetation cover, and larger- scale synoptic processes (Bales et al.,2006; Micu, 2015), resulting in snow measurements that exhibit considerable variability, between sites that are close together (Apostol, 2004; Apostol et.al., 2008). Likewise, there are studies ( Dumitrescu, 2017; Tveito, 2008) where the spatial interpolation procedure to estimate snow depth was applied. Hence, the Regression-Kriging (RK) spatial interpolation method was used and four interpolation methods were tested through the cross-validation procedure: Multiquadratic (MQ), Ordinary Kriging with separate (sepOK) and pooled semivariograms (pvOK) and 3D Kriging (K3d).

The same methodology is applied for the daily snow depth maps, which are online during cold season period on the official site of MeteoRomania. It can be accessed online at: www.meteoromania.ro.

Snow models are generally developed and applied to simulate snow accumulation and ablation processes and subsequently predict snowmelt. There have been numerous snow modeling studies simulating the mass and energy evolution and thus the snow water equivalent (SWE) of the snowpack via different models (e.g., SNOW17 of Anderson 1973, UEB of Tarboton and Luce, 1996; SAST of Jin et al. 1999, ESCIMO of Strasser et al., 2002; SNOWCAN of Tribbeck et al., 2004 and SE_Norge of Lussana et al., 2019).

These models offer promising way to provide spatial snow data to drive hydrologic forecast models because the SWE is a good indicator of the hydrological water cycle. For example, the heat exchange across the air-snow interface can be either positive or negative when the snow surface temperature drops below $0^{\circ} \mathrm{C}$ (Trenberth, K. et.al., 2017; Wayand et al.2017).

According with Anderson, 1976, the rate of heat exchange within the snow cover is largely a function of the effective thermal conductivity of the snow and for all the models noted above, the air temperature (Ta) has frequently been used to estimate snow melt. Also, early approaches used a simple degree day factor to compute the amount of melt water that would be produced by a snow cover on a daily basis. 
The forecaster generally has to make various updates to model states and computations and redo the simulations until there is a satisfactory agreement between computed values and observations (Sturm, 2010). Some of these updates are objective, but many are subjectively applied and require an interactive trial and error process to determine the proper adjustments and modifications can also be applied into the future in order to adjust melt estimates when abnormal weather conditions are predicted (Anderson, 1976).

\section{DATA AND METHODS}

\subsection{Data used}

The data used in this study were extracted from the climatic database of the Romanian National Meteorological Administration. The dataset contains no reconstructed records, like extensions or missing values filled by means of computational algorithms. We have used two input data required by SNOW 17 model:

1) Mean daily precipitation (for the $i$ day $=$ the cumulated precipitation between $18 \mathrm{~h}$ of the previous day and $18 \mathrm{~h}$ of the day i);

2) Mean daily temperature (average of the four measurements of the day, at 0 , 6,12 and $18 \mathrm{~h}$ )

For validating of the estimated values, measured daily snow depth (measured at 6 a.m. for the previous day) and snow water equivalent (measured or calculated at 6.a.m. for the previous day, with five days time step) were extracted. The SD measurements can be automated, in which the radar system has as its operating principle, and using the snow rules. They are installed in the autumn, about a month before the average date of the first snow fall and spring rises, when the weather conditions can no longer be favourable for the snow layer. The SWE represents the amount of water that would result from melting the snow layer. It can be calculated using following formula (1):

$$
\text { SWE }=\mathrm{d} \times \mathrm{H} \times 10,
$$

where SWE is snow water equivalent, $\mathrm{d}$ represents the snow density and $\mathrm{H}$ is the height of the snow layer. Whereas the SWE can be measured using the densimeter or the rain gauge, after determining its density. Snow from the cylinder is allowed to melt slowly away from heat sources. After the entire amount of snow has melted, the resulting water is carefully poured into the rain gauge, accurately reading the divisions on the tube. Hence, it can be easily understood that these determinations of the snow are subjective and involve human errors due to the meteorologist's skill and training. Also, measurement uncertainty consists of system error (resulting from the instruments) and representation error (resulting from aggregation of spatial variability in measured variables).

The information about the making meteorological measurements and observations can be find in the Meteorological Instructions of the Romanian National Meteorological Administration (ANM, 2017). 


\subsection{Methods}

Snow - model 17 is used to estimating the SWE and SD. This model is implemented by Anderson in 1973. It was firstly used in hydrological forecast. The approach used when developing SNOW-17 was to first try to represent the physical processes that occur in a column of snow. In order to get the average over the snowcovered area one must divide these mean areal values by the areal extent of the snow cover. The main processes included in the model for a column of snow are:

- Form of precipitation,

- Accumulation of the snow cover,

- Energy exchange at the snow-air interface.

Figure 1 shows a basic flowchart of the SNOW-17 model (Anderson, 2006).

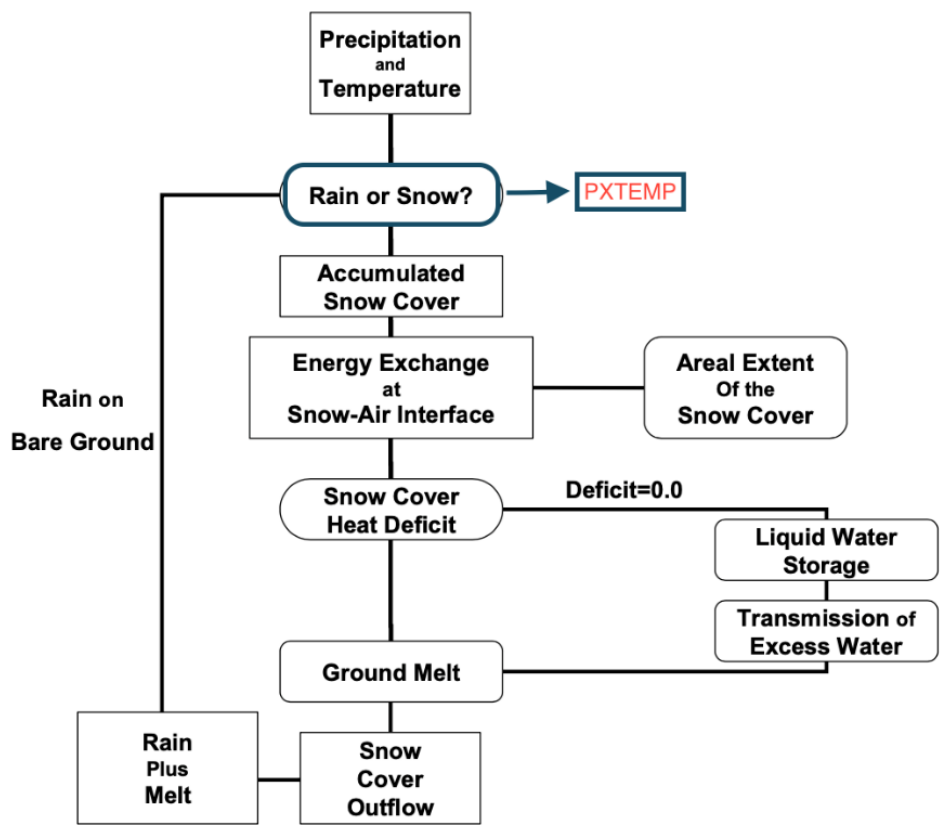

Fig. 1. Flowchart of the SNOW-17 model, after Anderson, 2006

Furthermore, SNOW17 is primarily controlled by 10 parameters when applied at the point scale (Figure 1 and Table 1) (Anderson, 2002; Franz et al., 2008; He et al., 2011). In the following sentences, it will present several conditions of the snow melt, according with the Anderson's methodology (Anderson, 1973; Anderson 2002). It requires air temperature and precipitation as inputs, while outputs include a rain plus snowmelt time series as well as SWE. The model doesn't provide the SD like output, so it is calculated using following formula (2): 


$$
S D=\frac{S W E}{d} 10,
$$

where: $\mathrm{SD}=$ snow depth, $\mathrm{SWE}=$ snow water equivalent and $\mathrm{d}=$ density of the snow.

SNOW-17 validate the form of precipitation values for a given computational time interval. Many studies (Lievens, 2019; He, 2007) shows that rain can occur at temperatures below $0{ }^{\circ} \mathrm{C}$ and snow can occur when the air temperature is $1{ }^{\circ} \mathrm{C}$.

\section{Table 1. Parameters of the SNOW17 Model with ranges estimated from Anderson (1973) and Franz et al. (2008)}

\begin{tabular}{|c|c|c|}
\hline Parameters & Details & Ranges \\
\hline SCF & Snow fall correction factor & $0.7-1.4$ \\
\hline MFMAX & Maximum melt factor & $0.5-2.0$ \\
\hline MFMIN & Minimum melt factor & $0.05-0.49$ \\
\hline PXTEMP & Temperature that separates rain from snow & $-2.0-2.0$ \\
\hline NMF & Maximum negative melt factor & $0.05-0.50$ \\
\hline UADJ & $\begin{array}{c}\text { The average wind function during rain-on-snow } \\
\text { periods }\end{array}$ & $0.03-0.19$ \\
\hline MBASE & Base temperature for nonrain melt factor & $0-1.0$ \\
\hline PLWHC & Percent of liquid water capacity & $0.02-0.3$ \\
\hline DAYGM & Percent of liquid water capacity & $0-0.3$ \\
\hline
\end{tabular}

From that study the typical temperature separating rain from snow is around $1.5^{\circ} \mathrm{C}$. A single threshold temperature is specified as a model parameter, referred to as PXTEMP (units of ${ }^{\circ} \mathrm{C}$ ). When the air temperature for the time interval is less than or equal to PXTEMP, all the precipitation is classified as snow. When the air temperature is greater than PXTEMP, all the precipitation is assumed to be rain. Gauge catch errors are accounted for using a snow correction factor SCF. Snowfall input to the model, Ps (mm), is calculated following the equation (3):

$$
P s=P \times f s \times S C F,
$$

where $\mathrm{P}(\mathrm{mm})$ is the observed precipitation and fs (dimensionless) represents the fraction of precipitation in the form of snow and is formulated as (4)

$$
f s=\left\{\begin{array}{l}
1, T_{a} \leq P X T E M P \\
0, T_{a}>P X T E M P
\end{array}\right.
$$

where $T_{a}\left({ }^{\circ} \mathrm{C}\right)$ represents the observed air temperature and PXTEMP $\left({ }^{\circ} \mathrm{C}\right)$ is the temperature that distinguishes snow- fall from rainfall.

SCF is an average value over all the accumulation periods used to calibrate the model. The value of SCF is typically chosen to give the best estimate of the amount 
of water in the snow cover at the beginning of the melt season. Notably is that SCF and PXTEMP $\left({ }^{\circ} \mathrm{C}\right)$ are the primary factors controlling snow input to the model. The density of new snow, $\rho_{n}\left(\mathrm{gm} \times \mathrm{cm}^{3}\right)$ is computed based on the air temperature (Anderson,1976) as (5)

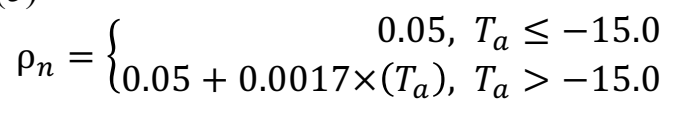

The SNOW-17 model calculates surface melt in different ways depending on whether rain is occurring or not. The model SNOW-17 expresses energy exchange in terms of $\mathrm{mm}$, where an $\mathrm{mm}$ of energy is the amount of heat required to melt or freeze $1 \mathrm{~mm}$ of ice or water, respectively, at $0{ }^{\circ} \mathrm{C}$.

Snowmelt during non-rain periods or very light rainfall amounts (less than or equal to $0.25 \mathrm{~mm} / \mathrm{hr}$ ) uses a melt factor to estimate the amount of surface snowmelt. Thus, the non-rain surface melt equation (6) is:

$$
M_{n r}=M_{f} \times\left(T_{a}-M B A S E\right) \times\left(\frac{\Delta t_{p}}{\Delta t_{t}}\right)+0.0125 \times P \times f_{r} \times T_{r},
$$

where $M_{n r}$ is melt during non-rain periods $(\mathrm{mm}), M_{f}$ is melt factor $\left(\mathrm{mm} /{ }^{\circ} \mathrm{C} / \Delta t_{t}\right)$, $\Delta t_{t}$ is time interval of temperature data and MBASE is base temperature $\left({ }^{\circ} \mathrm{C}\right)$.

MBASE is a model parameter that allows the user to vary the temperature above which melt typically occurs. A value of $\mathrm{MBASE}=0^{\circ} \mathrm{C}$ is recommended to use, though other values have been used in special situations, primarily when modelling a snow cover at a point location where the temperature measurements don't indicate when melt begins due to physiographic conditions at the site (Anderson,1973).

During rain-on-snow periods, snowmelt is primarily a function of the parameter UADJ. The model uses the energy balance to compute surface melt. Thus, SNOW17 uses a parameter, UADJ, to indicate the average wind function during rain-onsnow events. The equation for melt during rain-on-snow periods is (7):

$$
\begin{gathered}
M_{r}=\sigma \times \Delta t_{p} \times\left[\left(T_{a}+273 .\right)^{4}-273 .^{4}\right]+0.0125 \times P \times f_{r} \times T_{r}+ \\
8.5 \times U A D J \times\left(\Delta t_{p} / 6\right) \times\left[\left(0.9 \times e_{s a t}-6.11\right)+0.00057 \times P_{a} \times T_{a}\right],
\end{gathered}
$$

where $M_{r}$ melt during rain-on-snow time intervals (mm), $\sigma$ Stefan-Boltzman constant, $\Delta t_{p}$ is time interval of precipitation data (hours), $T_{a}$ air temperature $\left({ }^{\circ} \mathrm{C}\right), 273$. is $0{ }^{\circ} \mathrm{C}$ on the Kelvin scale, $f_{r}$ represents fraction of precipitation in the form of rain, $T_{r}$ is temperature of rain $\left({ }^{\circ} \mathrm{C}\right)-\left(=\mathrm{Ta}\right.$ or $0{ }^{\circ} \mathrm{C}$, whichever greater), UADJ (average wind function $(\mathrm{mm} / \mathrm{mb} / 6 \mathrm{hr}), e_{\text {sat }}$ is saturated vapor pressure at $\mathrm{Ta}(\mathrm{mb})-$ computed from :

$$
e_{\text {sat }}=2.7489 \times 10^{8} \times e^{\left(-\frac{4278.63}{T_{a}+242.792}\right)}
$$

and $P_{a}$ represents atmospheric pressure(mb) 
The parameter DAYGM ( $\mathrm{mm})$ is used to characterize geothermal heat flux at the ground surface and to allow for a constant melt rate at the soil-snow interface. A more detailed description of the SNOW17 model is given by Anderson (2002), Franz et al., (2008) and He et al. (2011).

The SNOW-17 model is coded in Fortran language. It was updated for the running on $\mathrm{R}$ programming language. Also, the code model can be accessed online at : https://github.com/tanerumit/sacsmaR/blob/master/R/snow17.R

\section{RESULTS AND DISCUSSIONS}

Here we reported the results obtained by SNOW17 model algorithm previously defined. Firstly, the computed values of SD compared with measured values show a good application of the model (Figure 1). The PXTEMP used in this model of SD was $0.0^{\circ} \mathrm{C}$. This value has been chosen as result of the tests running of the model with values ranged between $-2-+2{ }^{\circ} \mathrm{C}$. The maximum positive difference between modelled and measured has higher values at Petrosani station $(26.33 \mathrm{~cm})$, followed by Rosia Montana station. The lowest maximum positive difference has Miercurea Ciuc station $(12.5 \mathrm{~cm})$, followed by Piatra Neamt station.
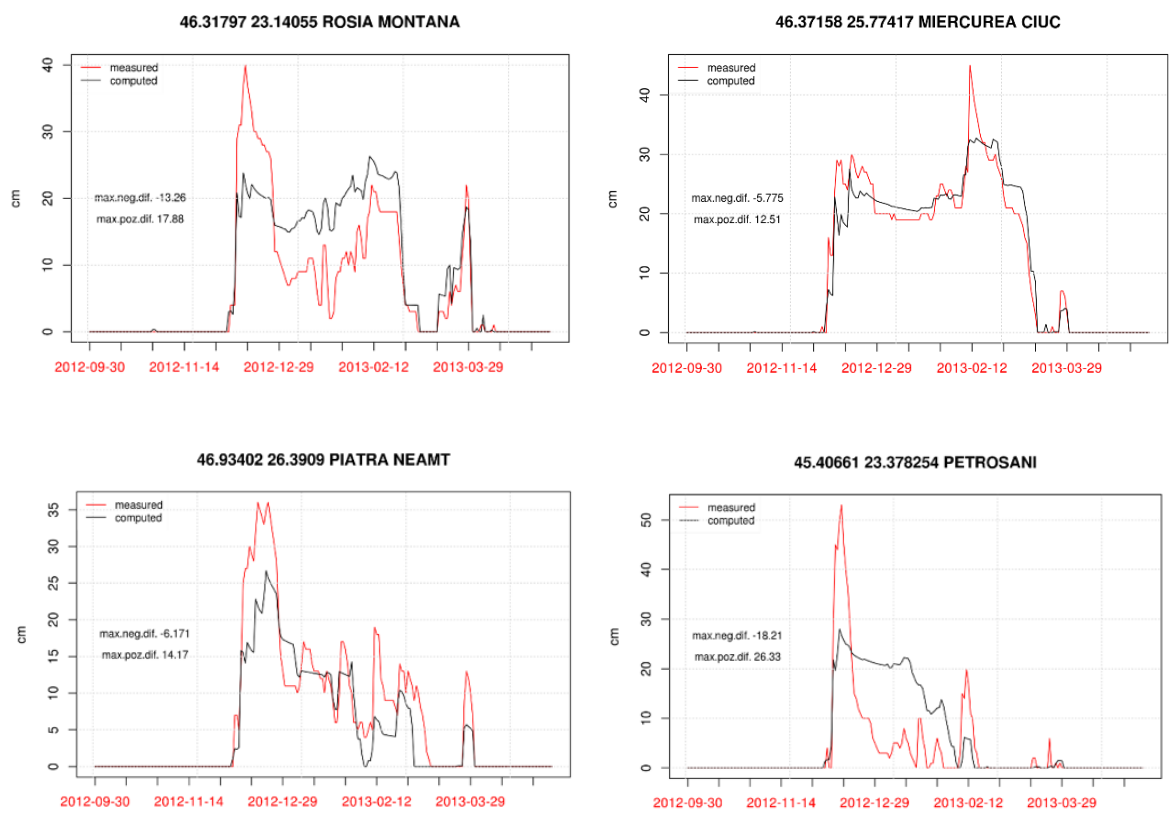

Fig. 2. The comparison between measured (line red) and computed values of the snow depth using SNOW 17 model for Rosia Montana Station(a), Miercurea Ciuc(b), Piatra Neamt(c) and Petrosani(d) in cold season (2012-2013)

A remark can be appreciated by the start and the end of the register period of snow depth. The computed values of SD are overestimated for all stations. The 
higher maximum negative difference between computed and measured are at Petrosani station $(-18.2 \mathrm{~cm})$. Miercurea Ciuc station has the lowest minimum negative difference $(-5.7 \mathrm{~cm})$, and not fair is Piatra Neamt station with $-6.1 \mathrm{~cm}$. In mountainous regions it can be raining at lower elevations and snowing higher up in the mountains.

The PXTEMP value was not default $\left(0^{\circ} \mathrm{C}\right)$. After many tests, the 1.8 $\operatorname{PXTEMP}\left({ }^{\circ} \mathrm{C}\right)$ was finally chosen. For the Predeal station the 0 PXTEMP $\left({ }^{\circ} \mathrm{C}\right)$ value was set for more correctly results. This means that variation of the rain-snow temperature threshold across stations varies with elevation and with the local conditions.

Jennings et al., 2018 discovered that averaging rain-snow temperature threshold is $1.0{ }^{\circ} \mathrm{C}$ and ranging from -0.4 to $2.4{ }^{\circ} \mathrm{C}$ for $95 \%$ of the stations in Northern Atmosphere. The thresholds are observed at upland elevations in continental regions.

Continental climates generally exhibit the warmest rain-snow thresholds and maritime the coolest. In fig. 3 the SWE results shows a strong correlation for Balea Lac meteorological station $(\mathrm{r}=0.97)$.
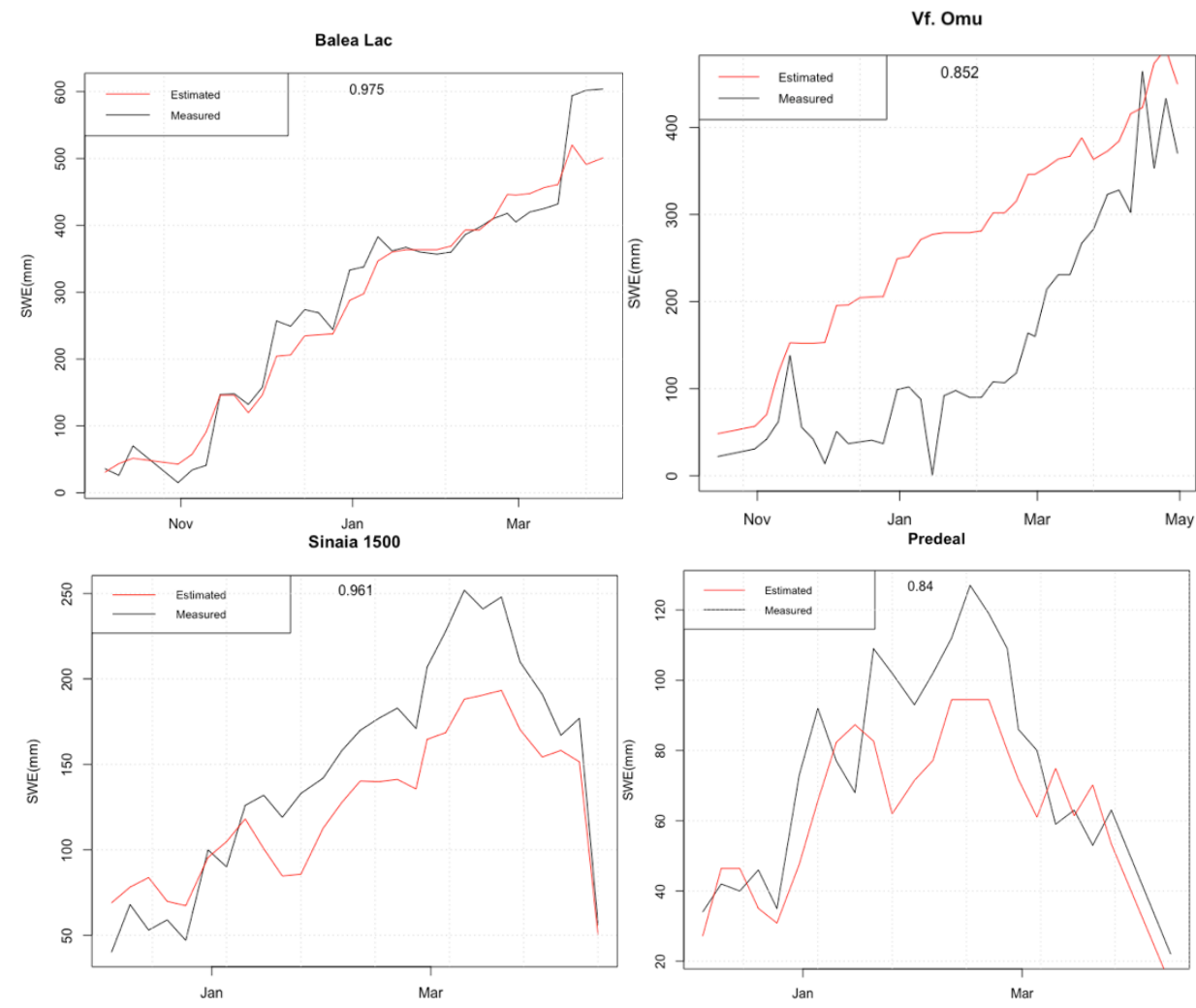

Fig. 3. The comparison between measured (line red) and estimated (black line) values of the snow water equivalent (SWE) using SNOW 17 model for Balea Lac Station, Vf. Omu, Sinaia 1500 and Predeal, in cold season (2012-2013) 
A weak correlation is represented by Predeal station $(r=0.84)$, followed by Vf Omu station (0.852). The last one is located at the highest altitude from the national meteorological station network in Romania $(2504 \mathrm{~m})$. The SWE estimated values are overestimated only for Vf. Omu meteorological station, whereas for other stations the values are notably underestimating.

\section{CONCLUSIONS}

Therefore, accurate estimates of the actual volume of snow and its spatial distribution are needed to provide quantitative estimates for more robust water supply estimates, flood forecasts, and resource- management decisions.

The temperature threshold rain-snow represent a notably parameter. It can modify the form of precipitation and by its values depends the output values of the model. In this reason, it must be intensively calculated for each meteorological station.

A study for the more accurate air temperature thresholds to partition rain and snow is need. The SWE estimate values largely depend on the PXTEMP values, more than the SD estimate values.

A greater difficulty in measuring the SWE and its subjectively measurements can influence the validation of the estimated data.

This study was a brief demonstration of a conceptual model (SNOW-17). It is very helpful because it can estimate several characteristics of the snow, like snow depth, snow water equivalent and density snow.

In the future research, we want to apply this model for gridded data, having like input, not only one station, but the raster of temperature and precipitation. The maps resulted can be uploaded on official site in operational mode. Moreover, using the temperature and precipitation forecasts we can forecast the snow depth and snow water equivalent too.

\section{REFERENCES}

1. Anderson, E. A. (1973), National Weather Service River Forecast System Snow Accumulation and Ablation Model, NOAA Tech. Memo. NWS HYDro-17, 217 pp., U.S. Dep. of Commer., Silver Spring, Md.

2. Anderson, E. A. (1976), A point energy and mass balance model of a snow cover, NOAA Tech. Rep. 19, 150 pp., U.S. Dep. of Commer., Silver Spring, Md.

3. Anderson, E. A. (2002), Calibration of conceptual models for use in river forecasting, NOAA Tech. Rep. NWS 45, Hydro. Lab., Silver Spring, Md.

4. Apostol, L., (2008), The Mediterranean cyclones-the role in ensuring water resources and their potential of climatic risk, in the east of Romania. Present environment and sustainable development, 2, pp.143-163. 
5. Apostol, L., (2004), Clima Subcarpatilor Moldovei. Editura Universităţii din Suceava.

6. Bales, R.C.,K.A.Dress;er,B. Imam,S.R. Fassnacht, and D.J.Lampkin (2008), Fractional snow cover in the Colorado and Rio Grande basins, 1995-2002, Water Resour., Res, 44, W01425.

7. Barnett, T. P., Adam, J. C. \& Lettenmaier, D. P., 2005), Potential impacts of a warming climate on water availability in snow-dominated regions. Nature 438, 303 309

8. Bojariu R, Dinu M. (2007), Snow variability and change in Romania, In Proceedings of the Alpine Snow Workshop, Munich, 5 - 6 October 2006, Strasser U, Vogel M (eds). Berchtesgaden National Park Report. 52: 6468.

9. Bojariu R, Paliu D. (2001), North Atlantic Oscillation projection on Romanian climate fluctuations in the cold season. In Detecting and Modelling Regional Climate Change and Associated Impacts, Brunet M, Lopez D (eds). SpringerVerlag: Berlin-Heidelberg; 345-356.

10. Brown, R. D., 2000: Northern Hemisphere snow cover variability and change 191597, J. Clim., 13, 2339- 2355

11. Cayan, D. R., Dettinger, M. D., Kammerdiener, S. A., Caprio, J. M. \& Peterson, D. $\mathrm{H}$ (2001), Changes in the onset of spring in the western United States. Bull. Am. Meteorol. Soc. 82, 399-415

12. Cline, D. W., R. C. Bales, and J. Dozier (1998), Estimating the spatial dis- tribution of snow in mountain basins using remote sensing and energy balance modeling, Water Resour. Res., 34(5), 1275-1285.

13. Dahe, Qin \& Liu, Shiyin \& Peiji, Li. (2006), Snow Cover Distribution, Variability, and Response to Climate Change in Western China. Journal of Climate - J CLIMATE. 19. 10.1175/JCLI3694.1.

14. Dumitrescu, A., Bojariu, R., Birsan, M. V., Marin, L. and Manea, A. (2015), Recent climatic changes in Romania from observational data (1961-2013), Theor. Appl. Climatol., 122, 111-119, DOI: 10.1007/s00704-014-1290-0.

15. Franz, K. J., T. S. Hogue, and S. Sorooshian (2008), Operational snow mod- eling: Addressing the challenges of an energy balance model for National Weather Service forecasts, J. Hydrol., 360, 48-66.

16. Grünewald, T., M. Schirmer, R. Mott, and M. Lehning (2010), Spatial and temporal variability of snow depth and ablation rates in a small mountain catchment, Cryosphere, 4, 215-225, doi:10.5194/tc-4-2152010

17. Jennings, K.S., Winchell, T.S., Livneh, B. et al. (2018), Spatial variation of the rainsnow temperature threshold across the Northern Hemisphere. Nat Commun 9, 1148 https://doi.org/10.1038/s41467-018-03629-7

18. Jin, J., X. Gao, S. Sorooshian, Z. L. Yang, R. Bales, R. E. Dickinson, S. F. Sun, and G. X. Wu (1999), One-dimensional snow water and energy bal- ance model for vegetated surfaces, Hydrol. Processes, 13, 2467-2482.

19. Krasting, J. P., Broccoli, A. J., Dixon, K. W. \& Lanzante, J. R. (2013), Future changes in Northern Hemisphere snowfall. J. Clim. 26, 7813-7828

20. Hamlet, A. F., Mote, P. W., Clark, M. P. \& Lettenmaier, D. P. (2007), Effects of temperature and precipitation variability on snowpack trends in the Western United States*. J. Clim. 18, 4545-4561.

21. He,M., Hogue,T.S., Franz, K. J., Margulis,S.A., and Vrugt,J. A. ( 2011), Corruption of parameter behavior and regionalization by model and forcing data errors: A 
Bayesian example using the SNOW17 model, Water Resour. Res., 47, W07546, doi:10.1029/2010WR009753.

22. IPCC. Climate Change (2018), The Physical Science Basis. Contribution of Working Group I to the Fifth Assessment Report of the Intergovernmental Panel on Climate Change (Cambridge University Press, Cambridge and New York, 2018).

23. Lievens, H., Demuzere, M., Marshall, H. et al. (2019), Snow depth variability in the Northern Hemisphere mountains observed from space. Nat Commun 10, 4629 https://doi.org/10.1038/s41467-019-12566-y

24. Lussana, Cristian \& Tveito, Ole \& Dobler, A. \& Tunheim, Ketil, (2019), seNorge_2018, daily precipitation and temperature datasets over Norway. Earth System Science Data Discussions. 1-27. 10.5194/essd2019-43.

25. Mankin, J. S., Viviroli, D., Singh, D., Hoekstra, A. Y. \& Diffenbaugh, N. S. (2015), The potential for snow to supply human water demand in the present and future. Environ. Res. Lett. 10, 114016

26. Micu D. (2009), Snow pack in the Romanian Carpathians under changing climatic conditions. Meteorology and Atmospheric Physics 105(1-2): 1-16. DOI: 10.1007/s00703-009-0035-6

27. Micu D.M., Dumitrescu A., Cheval S., Birsan M.V. (2015), Climate of the Romanian Carpathians. Variability and Trends, Springer. Cham, Elveția DOI: 10.1007/978-3-319-02886-6 7.

28. Micu D.M., Dumitrescu A., Cheval S., Birsan M.V. (2015), Regional Climatic Patterns, in book Climate of the Romanian Carpathians. Variability and Trends, Springer, Cham, Elveția, DOI: 10.1007/978-3-319-02886-6_7.

29. Prokop A., Assessing the applicability of terrestrial laser scanning for spatial snow depth measurements, (2008) Cold Regions Science and Technology, Volume 54, Issue 3, Pages 155-163, ISSN 0165-232X https://doi.org/10.1016/j.coldregions.2008.07.002.

30. Raisanen, J., U. Hansson, A. Ullerstig, R. Doscher, L. P. Graham, C. Jones, M. Meier, P. Samuelsson, and U. Willen (2003), GCM driven simulations of recent and future climate with the Rossby Centre coupled atmosphere Baltic Sea regional climate model RCAO. Reports on Meteorology and Climatology, No. 101, Swedish Meteorological and Hydrological Institute, $61 \mathrm{pp}$.

31. Stewart, I. T. (2009), Changes in snowpack and snowmelt runoff for key mountain regions. Hydrol. Process. 23, 78-94

32. Strasser, U., P. Etchevers, and Y. Lejeune (2002), Inter-comparison of two snow models with different complexity using data from an alpine site, Nord. Hydrol., 33, $15-26$.

33. Tarboton, D. G., and C. H. Luce (1996), Utah Energy Balance Snow Accu- mulation and Melt Model (UEB): Computer model technical description and users guide, Utah Water Res. Lab. Logan.

34. Trenberth, K. Changes in precipitation with climate change (2011), Clim. Res. 47, 123-138.

35. Tribbeck, M. J., R. J. Gurney, E. M. Morris, and D. W. C. Pearson (2004), A new snow-SVAT to simulate the accumulation and abla- tion of seasonal snow cover beneath a forest canopy, J. Glaciol., 50, 171-182. 
36. Wayand, N. E., Clark, M. P. \& Lundquist, J. D. (2017), Diagnosing snow accumulation errors in a rain-snow transitional environment with snow board observations, Hydrol. Process. 31, 349-363.

37. ***(2017), Administratia Nationala de Meteorologie, Instructiuni meteorologice, 2017, vol. I. 